\title{
New humanism or posthumanism? Ethical and legal aspects of the legalisation of euthanasia in the world in the years 2000-2015
}

\author{
Nowy humanizm czy posthumanizm? Aspekty etyczno-prawne \\ legalizacji eutanazji na świecie w latach 2000-2015
}

\author{
Andrzej Kobyliński \\ Institute of Philosophy, Cardinal Stefan Wyszyński University in Warsaw, Poland \\ ORCID: https://orcid.org/0000-0003-2252-8634 • a.kobylinski@uksw.edu.pl
}

\begin{abstract}
The main aim of this article is to outline the discussion on euthanasia that affects the basic aspects of human life - the foundation of human dignity, sense of pain and suffering, the conception of the afterlife, quality and value of life, etc. All the indications are that the process of the legalisation of euthanasia will develop in the coming decades. Today we need a new paradigm of bioethics, built on the basis of a new humanism, which will allow us to adequately analyse such phenomena as death, suffering and dying. The new paradigm of bioethics can be an effective tool in the dispute over the death on request.
\end{abstract}

Keywords: bioethics, euthanasia, Hans Küng, new humanism, posthumanism, persistent therapy

Streszczenie: Głównym celem tego artykułu jest przedstawienie dyskusji dotyczącej eutanazji, która dotyka fundamentalnych aspektów życia człowieka: podstaw ludzkiej godności, sensu bólu i cierpienia, rozumienia życia wiecznego, wartości i jakości życia itp. Wszystko wskazuje na to, że proces legalizacji eutanazji będzie postępował w najbliżzzych dziesięcioleciach. Dziś potrzebny jest nowy paradygmat bioetyki, zbudowany na nowym humanizmie, który pozwoli na adekwatną analizę fenomenów śmierci, cierpienia i umierania. Ten nowy paradygmat może być efektywnym narzędziem w dyskusji nad śmiercią na życzenie.

Słowa kluczowe: bioetyka, eutanazja, Hans Küng, nowy humanizm, posthumanizm, terapia uporczywa

\section{Introduction}

In the last few years, the process of legalizing euthanasia has significantly accelerated in many countries around the world. The year 2000 was a breakthrough in this respect, as the first legal act in the world legalizing termination of life on request was adopted in the Netherlands. The year 2015, in which various forms of voluntary termination of human life were considered legal in several other countries of the world, will probably also go down in history in the dispute over legal euthanasia.

Euthanasia is currently very often presented as the right of a sick person to die, which should be sanctioned by a specific law. Euthanasia in the strict sense is to be understood as an act or omission which, by its nature or in the intention of an actor, causes death in order to eliminate all suffering. Euthanasia means to bring death to oneself by a terminally ill person. It also

"This article was originally published in Polish as Kobyliński, Andrzej. 2015. "Nowy humanizm czy posthumanizm? Aspekty etyczno-prawne legalizacji eutanazji na świecie w latach 2000-2015." Studia Ecologiae et Bioethicae 13(4): 85-114. The translation of the article into English was financed by the Ministry of Science and Higher Education of the Republic of Poland as part of the activities promoting science - Decision No. 676/P-DUN/2019 of 2 April 2019. Translation made by GROY Translations. 
means to terminate life of a terminally ill patient, at their request, by medical personnel (Demmer 2004, 455-458).

The severity and complexity of the current dispute over legal termination of life on request is well illustrated by the unusual discussion that took place on 13 November 2014 in the German Bundestag. In many comments, it has been described as the most exciting debate in Germany over the last years. The discussion lasted five hours and was attended by 50 German parliamentarians. The great debate was even accompanied by the tears of some speakers, which is extremely rare among politicians in the Rhine country.

In Germany, the term "assisted dying" (Sterbehilfe) is most often used to describe a voluntary termination of life. Due to historical circumstances, the word "euthanasia" is very rarely used in German. In the era of National Socialism, the Germans implemented a programme of physical "Elimination of life unworthy of life" (Vernichtung von lebensunwertem Leben). The programme was called "Aktion T4". This action was also called "euthanasia" of the handicapped - hence the abbreviation "E-Action". Under that programme, at least 100 thousand sick and disabled people were killed in Germany and in the areas occupied by German troops. In 2015, the majority of Germans were in favour of legalising termination of life onrequest and active assisted suicide in the form of lethal injection by a physician on demand when the patient sees no reason for further treatment.

What conclusions can be drawn from legal acts legalizing euthanasia in some countries? How to morally judge euthanasia of children? Will the contemporary cultural trend, emphasizing the importance of the quality of life and the human right to death on demand, also dominate in the coming decades? How to respond to Hans Küng's challenge presenting religious arguments for the right to voluntary death? The article aims to analyse the process of legalizing euthanasia in many countries of the world in the years 2000-2015 and to show the need for a new bioethical paradigm as a remedy for the growing acceptance of the human right to death on demand.

\section{The Dutch Revolution of $\mathbf{2 0 0 0}$}

The Netherlands is the first country in the world to legalise euthanasia (Chabot 2007; Callebert en Van Audenhove 2012). The discussion about the "right to die with dignity" began in the country of tulips in the mid-1990s. In this country, already in 1990 euthanasia performed by physicians was no longer punishable. In practice, such a solution meant allowing physicians to "assist" terminally ill patients in suicide if they "unambiguously and repeatedly" demanded voluntary death. Another condition for the impunity of euthanasia was an incurable disease, causing unbearable suffering. The physician, before administering poison to the patient, also had to consult another physician (Fenigsen 1997).

In the Netherlands in the 1990s, each case of death upon request had to be reported to a special committee that examined whether euthanasia was justified in a given case. Unfortunately, in practice, physicians have quite often given up informing the committee about their actions to avoid additional formalities. Only in 1999, there have been more than 2,000 officially registered cases of physician-assisted suicide in the Netherlands, which probably accounted for only half of the euthanasia cases actually performed. At the end of the 1990s, public support for euthanasia reached as high as $92 \%$ in the country of tulips.

On 18 November 2000, the lower chamber of the Dutch Parliament legalised euthanasia with 104 votes in favour and 40 against. The Senate confirmed the decision of the lower house on 10 April 2001 with 46 votes "in favour" and 28 "against." The Act came into force on 1 April 2002. The law legalizing euthanasia is called: "Termination of Life on Request and Assisted Suicide (Review Procedures) Act" (in Dutch: Wet toetsing levensbeëindiging op verzoek en hulp bij zelfdoding).

The analysis of the law legalizing euthanasia in the Netherlands leads to two 
important conclusions. Firstly, the word euthanasia does not appear in the whole text at all. Secondly, the act contains 24 articles, of which only the first two deal with the conditions and criteria for shortening the life of a sick and suffering person. The remaining provisions concern purely technical issues that regulate, inter alia, the manner of informing about the patient's death and the functioning of committees supervising the cases of "unnatural death" reported by physicians.

It is worth emphasizing that the legislator does not define "termination of life on request", which should be understood as euthanasia. In the first article of the Act, however, "assisted suicide" is defined as voluntary assistance to other people in committing suicide or preparing the means for committing it. The second article of the act includes six criteria of "reliability, prudence and professionalism" which must be met by a physician in the event of termination of life on request or assisted suicide so that "unnatural death" is lawful (Wet 2014).

First, the physician must be convinced that the patient's request is voluntary, well-thought-out and final. Secondly, the physician must be sure that the suffering is unbearable, with no hope of improvement. Thirdly, the physician should inform the patient about their health situation and of the consequences thereof. Fourthly, the physician - along with the patient - must be convinced that, apart from accelerating the process of death, there is no other reasonable solution. Fifthly, the physician must consult another independent physician who shall visit the patient and express their opinion in writing with regard to respecting four previous principles of "reliability, prudence and professionalism". Sixth, termination of life on request and assisted suicide should always be accompanied by observing the principles of good clinical practice.

According to Dutch law, which legalizes euthanasia, a physician is allowed to fulfil a patient's request for voluntary death also in a situation where the patient is no longer able to express their will directly. In such a case, a written statement requesting the acceleration of death, previously signed by the patient consciously and voluntarily, is sufficient. It should be added that only the attending physician can be the one who decides to terminate life or assist the patient in suicide. In the legislator's opinion, only such a doctor knows the sick person well enough to be able to assess whether the patient expresses their request voluntarily, whether they considered it carefully and whether their suffering is really unbearable and without any prospect of improvement. However, a second physician, who acts as a consultant, cannot be involved in the treatment of the patient. Their task is only to assess the patient's health condition and the voluntary nature of their request for death, as well as to express their opinion in writing (Wet 2014).

In the Netherlands, a patient can submit their request for euthanasia orally or in writing. A written statement is especially important when a physician decides to terminate life when the patient can no longer verbally express a request for euthanasia. If, on the other hand, we are dealing with a patient's mental illness and suffering that does not originate from the body, the physician who decides to terminate the life must consult two independent experts, one of whom should be a psychiatrist.

In the Netherlands, any case of "unnatural death" must be reported to one of the five regional committees the task of which is to control deaths on request. The members of the committees are appointed by the state authorities for a six-year term. The committee must include a lawyer, a doctor and an expert in ethics. Based on the reports received, the committees shall assess whether the physician terminated lives or helped to commit suicide in accordance with the six principles of "reliability, prudence and professionalism". If any irregularities are found, the case is referred to the prosecutor's office (Wet 2014).

The legalisation of euthanasia in the Netherlands was accompanied by a special information policy of the government of 
that country. In this respect, the document prepared by the Ministry of Foreign Affairs was particularly important, as it precisely explained - in the form of 18 questions and answers - all the most important issues related to the legal transformation that took place in 2000. In this document, which was specifically addressed to international public opinion, the concept of euthanasia appears (The Netherlands Ministry of Foreign Affairs 2012). The Ministry of Foreign Affairs describes it as "termination of a patient's life by a physician". According to the Dutch government, the primary objective of the new law is to ensure maximum prudence in situations of "medical termination of life". The Ministry of Foreign Affairs made it clear that it was no longer possible to turn a blind eye to the well-known fact that euthanasia had long been practised in the country of tulips - hence the need for legal regulation of that phenomenon.

The state document explains that a physician cannot be forced to perform euthanasia or assist suicide. Physicians and nurses are allowed to refuse to participate in the preparation and cause of 'unnatural death'. The basis for such a ruling is the belief that "the patient does not exercise the right to euthanasia and that the physician is not obliged to practice it". In this context, the principle of conscientious objection appears, understood as the right of medical personnel to refuse to take actions contrary to their own moral and religious principles.

The Dutch Act of 2000 has become an important reference point for many similar solutions adopted in other countries. In the Netherlands, the law allows thousands of people to die on demand each year . Studies show that currently one case of "unnatural death" accounts for 30 natural deaths. One of the latest consequences of legal euthanasia was the opening of the End of Life Clinic (Levendseindekliniek) in March 2012. It is run by a very strong and influential organisation called the Dutch Voluntary End of Life Association: NVVE - Nederlandse Verenging voor een Vrijwillig Levenseinde (NVVE 2015). In 2013, the clinic admitted 749 patients, 134 of whom ended their lives there voluntarily. In the following year, there were 1,035 patients, 232 of whom chose to die on request (Faverzani 2015). In the country of tulips, this kind of hospital death is more and more often treated as a right for all citizens.

\section{The problem of child euthanasia}

The second country in the world to introduce legal euthanasia, in 2002, was Belgium. On 2 March 2014, King Philip of Belgium signed the act amending the law of 2002. The new solution adopted by the authorities in Brussels makes it possible to apply legal euthanasia also to children. Earlier, on 13 February 2014, the House of Representatives adopted the act by an overwhelming majority. In the vote of the lower house of the Belgian Parliament, 86 MPs voted in favour of the new law, 44 were against and 11 abstained. In this way, Belgium became the first country in the world to allow the euthanasia of children, without any age limit.

In 2002, also in the Netherlands, the possibility of euthanasia of minors was introduced, but this did not apply to children under 12 years of age. If the patient in the Netherlands is $16-18$ years of age, their request for termination of life is fulfilled provided that parents or legal guardians were involved in the decision-making process. On the other hand, in the case of children and adolescents aged 12-16 years, the request to terminate life or assist in suicide may be met by a physician only if the parents or legal guardians simultaneously agree.

The legalisation of child euthanasia in Belgium in 2014 was hardly noticed by the European public opinion. On the other hand, a serious worldview discussion has swept through the Belgian society over the past few years. In 2013, representatives of all the major religious denominations in Belgium were among those who signed a protest against the new bill: Catholicism, Lutheranism, Orthodoxy, Islam, Judaism and Buddhism. The joint document contains a warning against the logic that leads to the destruction of the foundations of social life. 
In the Belgian Act of 2014, the only criterion for a decision concerning death on request is the so-called ability to judge or discern. It occurs when there is a guarantee that what the child expresses is that what the child understands. The assessment of judgemental capacity is the responsibility of appropriate psychologists and psychiatrists of developmental age. The consent of the parents was not necessary in the earlier bill. This meant that even a very young child could claim euthanasia for itself. At the final stage of the parliamentary discussion, however, a clause concerning the need for parents' consent was added and a fragment was drawn up about psychological suffering, very common among adolescents, as one of the reasons justifying euthanasia.

In June 2015, Dutch Association of Paediatrics (Nederlandse Vereniging voor Kindergeneeskunde) has advocated extending the possibility of euthanasia to minors under 12 year of age. According to the Association, the age limit should be lowered in those cases where the child under 12 year of age shows the ability to understand the consequences of their decisions and the relevant medical choices. Thus, the country of tulips took the first step to "enter the road of Belgium, which in 2014 allowed the euthanasia of minors" (Schoepflin 2015b).

\section{The legalisation of euthanasia worldwide in 2015}

2015 was extremely important for the development of the phenomenon of legal euthanasia in the world. Appropriate acts, legalizing different forms of voluntary death, were adopted, among other, in Canada, France, Colombia and Argentina. On 6 February 2015, by a judgment of the Supreme Court of Canada, the socalled assisted suicide was legalized in this country. Nine judges passed the sentence unanimously. In this way, the Supreme Court supported the British Columbia Civil Liberties Association, which in 2009 filed a complaint requesting the possibility of euthanasia by Kay Carter and Gloria Taylor, two women affected by neurovegetative diseases.
In this way, one of the forms of euthanasia, which previously was legal in the province of Quebec only, was de facto legalised. The Supreme Court has legalised the so-called assisted suicide by removing the prohibition of such practice from the Canadian Penal Code. In the opinion of the judges, such a prohibition violated individual freedom, which also means the right to take one's own life (Scandroglio 2015a). The solution adopted in Canada means the possibility for an adult affected by a fatal illness and unbearable suffering, who has expressed their wish in writing, to take their own life.

In practice, a physician prescribes the medical means necessary for killing, while the patient takes their own life. In a written justification of the judgment, the Supreme Court of Canada confirmed that life is an inalienable good, but at the same time stated that the expression the "right to life" by no means implies an absolute prohibition on receiving assistance in terminating one's own life, nor does state that an individual cannot voluntarily give up their life. The court gave the Canadian parliament a year to pass a law on this matter.

Opponents of this solution, united in the Euthanasia Prevention Coalition, called on the federal government to establish a special commission in Canada to protect people with disabilities, the elderly, mentally ill and those at risk of suicide. In the summer of 2015, Euthanasia Prevention Coalition organized a campaign to send special postcards to the Canadian Justice Minister Peter MacKay, which called for appropriate care for the old, sick and suffering people.

The authorities in Paris also adopted an act legalizing some forms of death on request. On 17 March 2015, after the rejection of the draft law on assisted suicide a few days earlier, the lower chamber of the French Parliament adopted, by a large majority, the act on the rights of patients in the final phase of their lives. The new act allows terminally ill persons to benefit from "deep and lasting sedation" if they ask for it constantly, consciously and repeatedly 
(Scandroglio 2015b). Article 1 of the Act states that all persons have the right to a dignified end of life. Article 3 is the most debatable one, allowing the death of the patient if he or she so wishes, through the process of sedation, which consists in reducing the activity of the central nervous system due to the administration of strong doses of analgesics. The act stipulates that with the commencement of deep and permanent sedation, the feeding and hydration process of the patient who has decided to terminate their life must be discontinued.

French discussion on the deep and lasting sedation is accompanied by the dispute over the dramatic fate of Vincent Lambert, who since 2008 - as a result of a serious car accident - has been in a state of the so-called minimal consciousness at the University Clinic in Reims. The patient is breathing on his own, reacts to stimuli. His condition can be described as a profound disability. Several years ago, the hospital authorities wanted to interrupt the patient's assisted nutrition and hydration. Vincent Lambert's parents objected to this solution, while his wife accepted it.

A long and tumultuous judicial war began, culminating in the judgment of the European Court of Human Rights of 5 June 2015, which stated that it would not be illegal to interrupt nutrition and hydration in this case. After this sentence, however, Vincent Lambert was not killed. At the end of July 2015, doctors from the University Hospital in Reims requested the French judiciary to appoint an official legal guardian for the patient to defend his interests. In the summer of 2015, approx. 1700 patients in France were in a similar situation to that of Vincent Lambert (Vinai 2015).

Colombia has recently become another country with legal euthanasia. In April 2015, the Ministry of Health of this country has adopted guidelines on euthanasia (Verrazzo 2015). The decision, announced in the ministerial bulletin, was taken following the judgment of the Constitutional Tribunal of that country, which in February 2015 gave the government 30 days to define the rules for practising euthanasia. In Colombia, the parliamentary process was completely omitted when legalizing death on request. It is an absolute precedent on a world scale when it comes to regulating such a delicate sphere of life as the process of dying.

The document states that euthanasia might be requested by a terminally ill adult who has clearly expressed their will to end their life. If the patient has expressed such a decision, the treating physician is obliged to inform them about the possibilities of palliative care. If the patient upholds their request, the attending physician prepares a report on the objective state of their health. The case is then dealt with by a three-person interdisciplinary committee, composed of a specialist doctor, lawyer and psychologist, who again ask the patient if they confirm their will to take their own life. After the discussion with the patient, the committee prepares an appropriate report, which is accompanied by the report of the attending physician. If the patient does not change their mind, they can be euthanised within 15 days.

The group of countries accepting the right to voluntary death was also joint by Argentina. On 7 July 2015, the Supreme Court of that country (La Corte Suprema de Justicia de la Argentina) allowed the interruption of nutrition and hydration of Marcel Diaz, who had been in a vegetative state for 20 years. The patient died on the same day. Marcel's sisters had been soliciting such termination since 2011. This way, the door to the so-called passive euthanasia was opened. It was a turning point in the dispute over the legalisation of death on request in Argentina. La Corte Suprema de Justicia allowed voluntary death, even if the judgment assures that it is not a form of euthanasia. According to Argentinian judges, that case is similar to the story of Terry Schiavo from the USA, Elauna Englaro from Italy and recently Vincent Lambert from France (Schoepflin 2015a).

Italy is also another country in which there is currently a significant political and political controversy over the legalisation 
of death on request. In early 2015, the Italian opinion-making daily La Repubblica has published a series of articles promoting the legalisation of euthanasia in the country on the Tiber. A heated discussion on this topic began with the printout of an anonymous letter from one of the nurses at Careggi Hospital in Florence. In the letter, it was stated that euthanasia had been de facto practised in this hospital for a long time. At the same time, an anonymous nurse expressed her opinion that by supporting the patient artificially, we take the place of the Creator (Scandroglio 2015c).

After the letter was published, in the "La Repubblica"daily, euthanasia was strongly supported by, inter alia, prof. Umberto Veronesi - Italian oncologist, politician, scientific director of the European Oncology Institute. The well-known Italian writer, journalist and politician Corrado Augias took a similar position. One of the most important topics related to euthanasia, discussed in Bel Paese in the first half of 2015, was the issue of developing criteria to distinguish genuine euthanasia from discontinuation of persistent therapy. How do we understand today to sustain life to the very end? What should natural death be nowadays, when medicine has developed such excellent ways of prolonging life that we can already speak of many levels of the artificial and the unnatural?

In some of the statements for "La Repubblica", a postulate of legalisation in Italy of the so-called euthanasia by omission ( $\mathrm{eu}$ tanasia omissiva) was postulated. In such case, the medical personnel ceases to provide the patient with the means necessary to support the life process. That type of euthanasia should be distinguished from discontinuation of persistent therapy (rifiuto dell'accanimento terapeutico), which consists in the abandonment of administration of the means that are no longer relevant for the improvement of the patient's condition and life. In the first case, the death is caused, in the second case, the death is accepted as an inevitable phenomenon.

Undoubtedly, the task of doctors is to define the boundary - at the present stage of the development of medical knowledge between justified treatment and persistent therapy. It is very often an extremely difficult task because it involves both competence and conscience. Increasingly, medical personnel fear that they may be sued for acting in accordance with their own moral or religious beliefs. It seems particularly important today to ensure that the conscience clause is respected in the healthcare system so that decisions of doctors and nurses - in Italy and many other countries in the world - can be taken professionally and in accordance with conscience.

The Science \& Life Association (Associazione Scienza \& Vita) also took a voice in the Italian discussion on euthanasia. The organisation was established in 2005 as one of the fruits of the nationwide discussion conducted in Italy in preparation for the referendum concerning the act regulating the use of assisted reproduction methods. The mission of the Association is to create dialogue and reflection on human life and dignity. In practice, this means, inter alia, providing reliable information on bioethical issues, organizing scientific conferences, expressing bioethical positions in the context of various types of manifestations of the contemporary biotechnological revolution.

In press release 173 of 27 February 2015 entitled "Euthanasia in hospitals? Doctors and nurses heal, not kill", the Association responded to press releases about the practice of euthanasia in the Careggi hospital in Florence (Associazione Scienza \& Vita. 2015). According to the Science \& Life Association, many mass media deliberately manipulated the public opinion in this matter, because cases of justified discontinuation of persistent therapy were equated with the practice of euthanasia. Healthcare professionals must not succumb to this pressure. "The Hippocratic Oath and the Nurses' Oath are not optional, but are significant and distinguishing features of men and women who are at the service of others to help them live, not die" (Associazione Scienza \& Vita 2015).

The problem of legalizing euthanasia was also taken up by Great Britain. 26 July 
2015, the Catholic Church in England and Wales celebrated the Day for Life. The topic of this year's celebrations was: "Cherishing Life - Accepting Death". As part of the celebration of the Day for Life in 2015, 300,000 postcards devoted to defending the dignity of life of the elderly and the ill were distributed in England and Wales. This is one of the many initiatives of Catholics in these countries as part of a broad public awareness campaign on death and dying issues.

Just before the Day for Life, the European Court of Human Rights rejected the request for the legalisation of euthanasia submitted by some British activists who demanded the introduction of legalisation of assistance in the death of terminally ill people. The Strasbourg Court rejected complaints brought by Jane Nicklinson, whose husband Tony is paralyzed and suffers from Locked-in Syndrome, and by Paul Lamb, who is paralyzed after a car accident. In 2002, the Supreme Court of the United Kingdom has denied Tony Nicklinson the so-called the right to euthanasia. The Strasbourg Court did not consider these cases when it sent them to the British Parliament (Del Soldato 2015).

In August 2015, Lord George Carey, retired Anglican Archbishop of Canterbury, has spoken out in favour of medically assisted suicides. In his opinion, there is nothing noble about enduring excruciating pain. Deeply Christian and moral would be the establishment of a law that would allow those who choose to end their lives in dignity. Archbishop Carey is actively involved in the campaign to legalize assisted suicide. Meanwhile, the current Archbishop of Canterbury and the head of the Anglican community, Justin Welby, vehemently opposes legal liberalization in this regard.

On 11 September 2015, the House of Commons started a parliamentary discussion on the draft law on the legalisation of assisted suicide. The bill, prepared by Rob Marris, deals with the matter of assisted dying. The core of this project is to create legal opportunities for terminally ill adults to choose to be provided with medically supervised assistance to end their own life. In practice, this means that physicians legally administer lethal drugs to terminally ill patients who are expected to die within six months, so that they could commit suicide. The Marris Bill is in fact a copy of the law currently in force in the US state of Oregon. It is also a continuation of the Falconer Bill, which was previously rejected twice by the UK House of Commons.

\section{The Hans Küng challenge}

In 2013, Hans Küng - a Catholic priest who had been publicly questioning some of the contents of the Magisterium of the Catholic Church for many years - seriously challenged Christian thought when it comes to approaching euthanasia. The Swiss intellectual in the third volume of his memoirs entitled Experienced Humanity made a strong stand for the human right to voluntary death (Küng 2013). This was the first time a Catholic clergyman and a well-known theologian has shown his affirmative position so clearly when it comes to a form of termination of life on request. A year later, another book by this author was published, entitled Dying happily?. It is entirely devoted to the issue of the human right to a dignified death and develops the argumentation contained in the third volume of memoirs (Küng 2014).

The Swiss theologian's position on death on request is presented in his declaration: "Since I believe in eternal life, I am allowed - when the time is right - to make a decision, on my own responsibility, about the moment and manner of my dying" (Gerade weil ich an ein ewiges Leben glaube, darf ich, wenn es an der Zeit ist, in eigener Verantwortung über Zeitpunkt und Art meines Sterbens entscheiden). In his opinion, everyone has the right to end their life voluntarily when pain and suffering becomes unbearable. What is the essence of the challenge posed by the Swiss clergyman and intellectual? Some kind of Copernican Revolution, in this case, consists in religious and theological arguments in favour of the right to voluntary death. The Swiss theologian advocates the right to die 
on request because he is a believing Christian who recognizes that death is not the ultimate end of man.

Küng links the problem of death and dying very closely with his religious and theological views. He argues that his concept of dying in dignity and "a dignified end of life" (ein menschenwürdiges Ende des Lebens) has nothing to do with suicide or euthanasia. He claims that a happy death to him does not mean dying without melancholy or pain, but leaving, accompanied by the reconciliation with fate, deep satisfaction and inner peace. In his opinion, this is what the Greek word euthanasia means - happy, good, just and beautiful death.

The Swiss theologian believes that the right of man to decide when they die does not contradict the Christian religion and the duty of respect for life. The Christian God is merciful and he is not a cruel tyrant who wants his children to suffer, which becomes a goal in itself. This author's current attitude to death results from his many years of intellectual and spiritual effort to understand issues such as the existence of God, the essence of Christianity, eternal life, the Church, ecumenism and world's religions.

Küng's current position on the right to voluntary death was also greatly influenced by his personal life stories, including the disease of his brother George who died of brain cancer at the age of 23, and the long-standing dementia of a close friend Walter Jens. The Christian faith and life experiences led the Swiss theologian to the conviction that a dignified death on request is an inalienable human right (Wehrli, Sutter, and Kaufmann 2015).

The author of the book Dying happily? was long a member of the Swiss "Exit" Association, which is one of the most world-renowned organizations that assist terminally ill in suicide. Küng says he agrees with the declaration of the Parliament of the World's Religions, issued in Chicago in 1999, which commits a culture of respect for all life - in line with the statements: "Don't kill!" and "Respect every life". They mean that all people have the right to life - to preserve their own physical integ- rity and the free development of their personality, as long as they do not infringe the rights of others. No human has the right to physically or mentally torture other people. Precisely because the human person is infinitely precious, it is imperative to protect their dignity until the very end. Today, in the era of rapid medical development, it is necessary to carefully consider what it really means to die with dignity, when modern medical procedures can make dying a painless process or are able in many cases to significantly delay the moment of our death (Jens and Küng 2009).

The Swiss theologian does not deny the religious truth that life is a divine gift. Yes, it is a gift from God, but God has put it at man's responsible disposal. This also applies to the last stages of the process of life and death itself. A man should make an independent decision on the determination of the moment of their death in the spirit of moral autonomy and self-determination (Selbstbestimmung des Menschen), which for Immanuel Kant was the source of human dignity.

How to "independently" (eigenständig) define the moment of one's own death? When is the right time to leave the Earth's life? One should read it in own conscience in order to responsibly say goodbye to the earthly existence. In November 2013, at the German Society for Human Dying (Deutsche Gesellschaft für Humanes Sterben) conference speaking in Bonn, Küng publicly confessed that God had not yet given him any direct sign from heaven in this matter. He added that he hoped that God would give him the grace to recognise the right moment - the latest moment would undoubtedly be the onset of dementia.

\section{The need for a new bioethical paradigm}

The wave of legalisation of various forms of voluntary death sweeping through the world raises the question about the type of bioethical analysis and argumentation that we will need in the coming decades. The year 2015 clearly showed that the hypotheses that various kinds of anti-euthanasia actions "may bring about any change 
of tendency in the foreseeable time" are totally unrealistic (D'Agostino 2015). In many countries of the world, the vision of medicine in the spirit of Hippocrates is being abandoned more and more often, for whom the doctor's duty should always be to take action that serves life, not death.

Francesco D'Agostino claims that today "it is imperative to take a step forward which is extremely difficult because it is completely new: it is not necessary to reformulate but to formulate a new bioethical paradigm at the conceptual and communicative level, which will not consist in re-proposing the so-called traditional values. It is necessary to develop proposals for actions and new values - inspiring, provocative and radically antithetical to those practices and values that led to the adoption of laws for euthanasia" (D'Agostino 2015).

D'Agostino believes that an example of such activities under the new bioethical paradigm may be the relation between the health care system and the third age. The last stage of human life in the secularized societies of Western civilization has been almost entirely dominated by medicine and bureaucracy. We have to get out of this road and make a gradual positive "privatization" of our life, and especially of our death, because the only truly human place for our dying is the family life full of good feelings. More and more doctors in the world are convinced that the hospital is not a good place for the elderly or terminally ill people. The abandoned sick and old people dying in loneliness are a consequence of the family crises. According to D'Agostino, it is necessary to expose contemporary individualism, revealing a new horizon of human rights and emphasizing the inalienable essence of our humanity.

One of the American models of care for the elderly may prove the effectiveness of the new bioethical paradigm. One of its creators is Brad Stuart - a doctor, specialist in palliative medicine, working in the network of hospitals and clinics of Sutter Health, which has its facilities in 100 cities in California (Molinari 2015). Stuart created the first in the USA program to man- age incurable diseases. The idea behind the programme is very simple - teams of specialists from many branches of medicine are formed for the care of terminally ill patients and visit patients in their homes. It is primarily about changing the approach - the goal is not a medical procedure, but care for the person we help to meet their personal expectations.

The new method of care not only emphasizes the dignity of ill and suffering people but also extends their lives and brings significant savings to the health care system in the US, $5 \%$ of terminal patients generate over half of all health care spending. On 23 August 2015, Stuart presented his model of palliative care in Rimini, Italy, at the "Meetings of Friendship between Nations" (Meeting per l'amicizia fra $i$ popoli).

The development of a new bioethical model is also associated with the intellectual challenges of modern atheism. In many regions of our globe, an atheistic vision of the world and man has recently been strengthened. One of such countries is the United States. The so-called Stratonic Atheism, which refers to the views of the Greek philosopher and perpathet Straton of Lampsak (335-269) has been recently very fashionable there. Straton was primarily concerned with the natural sciences. Like the atomists Leucyp and Democritus of Abdera, he was a materialist and believed that everything in the universe was built of matter and energy.

Straton interpreted the universe as a mechanism in which no forces of a divine, transcendent or religious nature existed. Straton and his followers today believe that each rational discussion about God should begin by assuming the truth of atheism as a common sense view. In this perspective, the atheistic vision of the world and man is presented as the only rational and obvious concept. As a consequence, the duty to prove the opposite thesis, i.e. the rationality of the arguments concerning the existence of the Supreme Being, rests with those who adhere to religious beliefs.

Such theses are presented, among others, by two atheistic American philoso- 
phers Scott F. Aikin and Robert B. Talisse in a book published in the USA in 2011 entitled Reasonable Atheism (Aikin, and Talisse 2011). According to these authors, atheism is an absolutely rational attitude. The only problem is to convince the adherents of the theistic worldview of the internal rationality of the atheistic worldview. The monograph of American authors is "apologetic" in its nature - its main purpose is to philosophically prove to theists that the choice of atheists has an exceptionally solid rational basis. Therefore, an atheistic vision of the world should be considered an attitude worthy of respect from a moral and intellectual point of view. The book is a kind of reversed fundamental theology - it is a new summa atheologica that demonstrates the rationality of atheism as the most convincing philosophical position.

Unlike Richard Dawkins and many other so-called new atheists who present hostile attitudes towards religion, Aikin and Talisse avoid aggressive or offensive tones towards people with religious beliefs. They prefer the soft approach - in their opinion, one should respect different views, and nobody should be offended. The main purpose of the book is to show the adherents of the theoretical vision of the world that such ideas as the existence of the Supreme Being, sin, and miracles are contrary to reason. This means deconstruction of all kinds of ontological, cosmological or anthropological arguments for the existence of the Supreme Being (Timossi 2015). Stratonic Atheism poses a serious intellectual challenge to bioethics and today's disputes over euthanasia, because it forces to deeply reflect on the foundation of human dignity, the meaning of suffering and dying, and the perspective of the afterlife.

One of the authors who perceive the challenge of contemporary atheism is the American philosopher H. Tristram Engelhardt, who published in 1986 his widely commented book "The foundations of bioethics" (Engelhardt 1986). In 2000, his next work titled "The foundations of Christian bioethics" was published (Engelhardt 2000). It is a testimony to the many chang- es in the author's thinking that followed his abandonment of Catholicism and the conversion to Orthodoxy in the mid-1990s. Engelhardt claims now that Christianity has de facto collapsed. A similar fate befell modernity, in which moral rationality disintegrated into a kind of polytheism of ethical concepts. In his opinion, a civilization built on a Christian foundation has practically ceased to exist, but God still exists and remains our ultimate point of reference today (Engelhardt 2014).

The author of "The foundations of Christian bioethics" claims that human reason is not able to cognize the Supreme Being in a natural way. Engelhardt sharply criticizes Western Christianity, which he accuses of having throughout history preferred Athens over Jerusalem, opening the way for the primacy of reason over faith. Consequently, today we face the need to dehellenise Christianity. There is no moral philosophy that is universal in nature. So it is impossible to build any rational ethics in the planetary dimension. In his opinion, secular bioethics and secularized Christian bioethics are not able to effectively protect the sanctity and dignity of human life today. The only solution is to replace human reason by the Orthodox Christian faith and by Tradition. Engelhardt claims that only such strictly religious bioethics can effectively defend human dignity today.

\section{New humanism versus posthumanism}

The search for a new bioethical paradigm is closely related to the contemporary reflection on new humanism and posthumanism. Many interesting comments on this subject have recently been formulated, among others, by French intellectual Julia Kristeva.

Based on what vision of man a new bioethical paradigm will be built in the future? Which trend will dominate the next decades: new humanism or posthumanism? How to justify human dignity and the meaning of suffering and dying, if the posthumanist vision prevails in the coming times? The answers to these questions will depend on, among others, bioethical 
analysis of the euthanasia phenomenon and the quality of the law created in this matter.

In 2015, the issue of new humanism and posthumanism became an extremely important element of public debate in Italy - especially thanks to the 5th National Church Convention (Convegno ecclesiale nazionale), which took place in Florence on 9-13 November 2015. The previous edition of this extremely important event in the life of the Catholic Church in Italy was held on 16-20 October 2006 in Verona. During the National Church Conventions, Italian Catholics seek answers to the most pressing moral, religious, social, cultural and philosophical challenges of the present time (Diaco 2015; Tommasi 2015). The theme of the 2015 Convention was: "In Jesus Christ, a new humanism" (In Gesù Cristo il nuovo umanesimo).

Preparations for the Florence Convention took many years. As part of the preparations, many scientific symposia were organized. One of such conferences took place on 24-27 August 2015 in Collegio Rosmini in Stresa near Milan. It was the 16th Rosmini Symposium (Simposi Rosminiani), the topic of which was: "Person, psyche and society. In search of what is human" (Persona, psiche e società. Sulle tracce dell'umano). Many of the issues raised during this conference were an anticipation of the debate and reflection that took place at the National Church Convention in Florence. On the first day of the symposiums, an extremely important lecture on the concept of person, personalism and contemporary ideological colonialism was delivered by Nunzio Galantino, Secretary General of the Italian Episcopal Conference (Galantino 2015).

The problem of the new humanism as a response to the contemporary axiological crisis was also present in the discussion that took place in Italy in connection with a demonstration that took place on 20 June 2015 in Rome on St. John's Square in the Lateran. The demonstration was organized by the "We Defend Our Children" Committee (Difendiamo $i$ nostri figli). During the demonstration, one million people protested against the bill on the legalisation of single-sex couples and the introduction of gender ideology into Italian schools.

In preparation for the 5th National Church Convention, many books and articles have been published in Italy. One of the most interesting items is the study by Giuseppe Savagnone entitled Quel che resta dell'uomo. É davvero possibile un nuovo umanesimo? (What remains of man. Is a new humanism truly possible?) (Savagnone 2015). According to the author, humanism involves the content of the nature of a human being, human nature, the meaning of human life, a vision of a fulfilled and happy life or a model of collective life. The deepest essence of the present crisis of modern humanism lies in a kind of ambiguity or uncertainty about what is genuinely human and which is testifying to our identity.

"There is a risk," says Giuseppe Savagnone, "that instead of facing real challenges and seeking answers to the questions posed by the culture of our time, they are treated negligently, taking the necessary solutions as simple and obvious. If this happened, the formula of the new humanism would be held hostage to a certain pastoral practice that feeds the superficiality and mental laziness of the majority of the faithful, tacitly accepting their lack of cultural commitment and exempting them once again from the effort to overcome the gap that now separates, in many respects, the contemporary world from the Gospel" (Savagnone 2015, 5).

Savagnone understands the new humanism as a rediscovery of the nature of Christian humanism, the nature of which is the idea of the Incarnation and the divinity of man. In this perspective, the relationship with the Supreme Being is the source of human dignity - God became man so that in their human face "man could recognize their own divine face" (Savagnone 2015, 176). According to this author, an authentic search for a new humanism must take into account the five most important issues nowadays. 
The first concerns the relationship between humanism and ecology and animism. These two currents of modern thought strike the very heart of the uniqueness of human existence and its superiority to other living beings. Can human dignity be valued in dialogue with ecology and animism? How to maintain the distinctness of the human being?

The second issue relates to the relationship between human nature and the world of technology. Are we able today to defend the notion of human nature as the essence of humanity, which is not subject to change, as modern technological development blurs more and more the distinction between what is natural and what is artificial and man-made?

The third issue concerns the relationship between the individual and society. How to protect the autonomous existence of a human being against the threat of individualism and the lack of social ties? How to stop the advancing crisis of family life that has a colossal impact on living out old age and understanding death and dying?

The fourth issue concerns the person's identity based on biological gender and the problem of sexual orientation. Does sexuality naturally define a person's identity or is it a historical and cultural structure that now needs to be broken down so that people can freely choose their own sexual orientation?

The fifth point relates to the challenges posed by posthumanism nowadays. Is there any sense in talking about humanism in the era of posthumanism today? Are the humanistic ideas still valid? If they are in fact historically and culturally conditioned, perhaps they will end just as they once began?

One of the authors analysing the phenomenon of posthumanism in the country on the Tiber is the Italian philosopher Luca Grion. In his opinion, posthumanism - as a current of thought that seeks to strengthen human nature and expand its possibilities - is like an archipelago that consists of many islands surrounded by the waters of the same sea or ocean. The situation is similar with posthumanism - within this trend, one can find a great variety of visions of the future, the common element of which is the belief that the human being as we know it today - with his existential fragility and various types of limitations - is approaching the moment of radical transformation in the coming decades. According to this vision of the future, the technological development of our civilization will make the human subject "posthuman" (postumano), and humanism will be defined definitively as a closed heritage to which there is no return (Grion 2012).

Another Italian intellectual, Vittorio Possenti, also draws attention to the challenges posed by posthumanism in his writings. In his opinion, posthumanism is one of the forms of development of secular humanism which strongly emphasizes the role of science and technology. "Technophiles, futurists, prometists, technognostics - says Possenti - form a galaxy of the posthumanist movement, for which scientific and technical rationality is the root of the West - possibly combined with utilitarian rationality and, above all, with the libertine idea of man As a consequence, posthumanism is considered a natural consequence of all Western culture. In posthumanism there are also tendencies hostile to religion, especially towards Christianity, while here and there the pagan and neo-pagan roots of Europe are sought" (Possenti 2013, 41).

Proponents of posthumanism are convinced that the development of technology allows us to overcome diseases in the future, solve the problem of old age and develop our memory. Posthumanists believe that our psychological identity will be transferred to digital media. The future outlined by the gurus of posthumanism is to some extent fulfilled before our eyes. The methods of artificial insemination and genetic engineering already allow for designing a new generation of children that can be created according to the parents' expectations. Large research projects (e.g. US Brain Iniziative or Human Brain Project) seek to create digital brains that would be equivalent to human minds. 
Extensive research on the possibilities of anti-aging process is currently being conducted by, among others, the American Department of Defense.

The dispute between the new humanism and posthumanism is of decisive importance for the future of euthanasia in the world. Based on the ideas of the new humanism a new bioethical paradigm can be created that could be an effective remedy for the developing process of the legalisation of death on demand. The possible domination of post-humanist ideas will make it extremely difficult to oppose various forms of voluntary death.

\section{Conclusions}

The worldwide process of legalizing various forms of death on demand requires extensive interdisciplinary research. Deep philosophical and cultural reflection is needed, among other things, to analyse the conditions of extremely broad social consent for practising euthanasia. One of the main reasons for this situation is undoubtedly the progressive technologicalisation of life and the crisis of the family and people-to-people links. Today, due to the rapid development of medicine and weakened sensitivity to transcendence, the experience of suffering, pain and dying takes on a completely new meaning. If the tendency to consider life as valuable only to the extent that it is a source of pleasure, happiness and prosperity begin to prevail, then suffering and old age appear to be an unbearable burden, from which one must be freed at all costs. Then death on request becomes a form of liberation.

The legalisation of euthanasia in many countries of the world draws attention to the need to effectively promote the idea of discontinuing persistent therapy (Abel $2004,4-7)$. Unfortunately, very often it is a completely forgotten or marginalized category. Therefore, in many cases of death on request, euthanasia is completely wrongly referred to where there has only been the discontinuation of persistent therapy. Discontinuation of medical procedures that are costly, risky, extraordinary or disproportionate to the expected results is the discontinuation of persistent therapy and has nothing to do with euthanasia. It is not intended to inflict death in this way; it is merely assumed that it cannot be prevented in this case. Developing clear criteria to distinguish euthanasia from discontinuation of persistent therapy has been one of the most important bioethical challenges today.

The global process of legalizing various forms of voluntary death highlights the role of palliative care. In France in 2015, there were opinions that the adoption of the End of Life Act in this country is, among other things, the result of years of neglect in the field of palliative therapy. In many countries, a multitude of doctors, nurses, psychologists and volunteers participate in palliative care. The aim of palliative therapies is to alleviate the suffering in the final stage of disease and to provide the patient with the support it needs. In this context, the problem of the fair use of various types of painkillers and tranquillizers emerges, when it is associated with the risk of shortening life.

Unfortunately, everything seems to indicate that the process of legalisation of euthanasia will develop in the coming decades. A serious challenge to bioethics and Christian thought are, among others, proposals by Hans Küng, who presents religious arguments in favour of the human right to voluntary death. The Swiss theologian questions the position of the Magisterium of the Catholic Church on euthanasia. To effectively challenge Hans Küng's approach to voluntary death, a very clear bioethical argumentation is needed to show various forms of euthanasia as a violation of the holiness and dignity of human life. There is no doubt that what we need today is a new bioethical paradigm, built based on a new humanism, which will allow us to adequately analyse such phenomena as death, suffering or dying. The new bioethical paradigm may help to stop the wave of legalisation of various forms of euthanasia in many countries of the world. 
The dispute over euthanasia is an extremely important element of modern cultural war. It concerns the basic issues related to human life - the foundation of human dignity, the sense of pain and suffering, the quality of social relations, the vision of the afterlife, human freedom, quality and value of life, etc. It can be said that the global discussion on the legalisation of various forms of death on request is not so much about how some of us will die, but about how we will all live and how we will understand the meaning of our existence.

\section{Bibliography}

Abel, Francesc. 2004. "Accanimento terapeutico." In Nuovo Dizionario di Bioetica, edited by Leone Salvino e Privitera Salvatore, 3-8. Roma - Arcireale: Città Nuova Editrice - Edizioni ISB dell'Istituto Siciliano di Bioetica.

Aikin, Scott F., and Robert B. Talisse. 2011. Reasonable Atheism: A Moral Case For Respectful Disbelief. Minnesota: Prometheus Books.

Associazione Scienza \& Vita. 2015. Eutanasia negli ospedali? I medici e gli infermieri curano, non sopprimono. Accessed August 28, 2015. http://www.scienzaevita.org/category/ news-press/comunicati-stampa.

Callebert, Ann en Chantal van Audenhove. 2012. Euthanasie. Bij ondraaglijk psychisch lijden. Leuven: Uitgeverij Acco.

Chabot, Boudewijn. 2007. Auto-euthanasie. Verborgen stervenswegen in gesprek met naasten. Amsterdam: Bert Bakker.

D’Agostino, Francesco. 2015. „Lo scandalo eutanasia chiama a valori saldi." Avvenire 77: 3 .

Del Re, Giovanni M. 2015. Il Belgio dice „si” all'eutanasia sui bimbi. Accessed August 28, 2015. http://www.avvenire.it/Vita/Pagine/ eutanasia-minori-in-belgio-al-voto.aspx.

Del Soldato, Elisabetta. 2015. „La Chiesa inglese in campo sul fine vita." Avvenire 185: 470.

Demmer, Klaus. 2004. „Eutanasia.” In Nuovo Dizionario di Bioetica, edied by Leone Salvino e Privitera Salvatore, 455-459. Roma - Arcireale: Città Nuova Editrice - Edizioni ISB dell'Istituto Siciliano di Bioetica.

Diaco, Ernesto. 2015. Il futuro ha un cuore antico. Il contributo di Firenze per un nuovo umanesimo. Urbino: Città Ideale.
Engelhardt, H. Tristram. 1986. Foundations of Bioethics. New York Oxford: University Press.

Engelhardt, H. Tristram. 2000. Foundations of Christians Bioethics. Lisse: Swetsand Zeitlinger Publishers.

Engelhardt, H. Tristram. 2014. Dopo Dio. Morale e bioetica in un mondo laico. Torino: Claudiana Editrice.

Faverzani, Mauro. 2015. Casi di eutanasia in crescita nella clinica di fine vita. Accessed August 28, 2015. http://www.corrispondenzaromana.it/casi-di-eutanasia-in-crescita-nella-clinica-di-fine-vita/.

Fenigsen, Ryszard. 1997. Eutanazja. Śmierć $z$ wyboru? Poznań: Wydawnictwo „W drodze".

Firth, Lisa. 2011. Euthanasia and Assisted Suicide. Cambridge: Independence Educational Publishers.

Galantino, Nunzio. 2015. "Personalismo, vera anti-ideologia." Avvenire 200: 21.

Grion, Luca. 2012. Persi nel labirinto. Etica e antropologia alla prova del naturalism. Milano: Mimesis.

Huxtable, Richard. 2013. Euthanasia. London: Hodder \& Stoughton.

Jackson, Emily, and John Keow. 2011. Debating Euthanasia. Oxford: Hart Publishing.

Jens, Walter, and Hans Küng. 2009. Menschenwürdig sterben. Ein Plädoyer für Selbstverantwortung. München: Piper Verlag.

Küng, Hans. 2013. Erlebte Menschlichkeit: Erinnerungen, v. III. München: Pieper Verlag.

Küng, Hans. 2014. Glücklich sterben? Mit dem Gespräch mit Anne Will. München: Pieper Verlag.

Molinari, Elena. 2015. "La miglior cura è a casa del paziente." Avvenire 179: 18.

NVVE 2015 - Nederlandse Vereniging voor een Vrijwillig Levenseinde. https://www. nvve.nl/.

Pitcher, George. 2010. A Time to Live: The Cases Against Euthanasia and Assisted Suicide. Oxford: Monarch Books Publishers.

Possenti, Vittorio. 2013. La rivoluzione biopolitica. La fatale alleanza tra materialismo e tecnica. Torino: Edizioni Lindau.

Remuzzi, Giuseppe. 2015. La scelta. Perché è importante decidere come vorremmo morire. Milano: Sperling \& Kupfer. 
Ricca, Paolo. 2002. Eutanasia. La legge olandese e commenti. Roma: Claudiana Editrice.

Savagnone, Giuseppe. 2015. Quel che resta dell'uomo. È davvero possibile un nuovo umanesimo? Assisi: Cittadella.

Scandroglio, Tommaso. 2015a. Omicidio di Stato? No, chiamatelo „suicidio assistito”. Accessed: August 28, 2015. http://www.lanuovabq.it/it/articoli-omicidio-di-stato-no-chiamatelo-suicidio-assistito-11767.htm.

Scandroglio, Tommaso. 2015b. „Sedazione profonda": è l'eutanasia alla francese. Accessed August 28, 2015. http://www.lanuovabq.it/it/articoli-sedazione-profonda-e-leutanasia-alla-francese-12131.htm

Scandroglio, Tommaso. 2015c. Eutanasia, $i$ due errori "mortali” del dolce Augias. Accessed August 28, 2015. http://www.lanuovabq.it/it/articoli-eutanasia-i-due-errori-mortali-del-dolce-augias-11959.htm.

Schoepflin, Lorenzo. 2015a. „Anche l'Argentina scopre l'eutanasia per sentenza." Avvenire 167: 469.

Schoepflin, Lorenzo. 2015b. Olanda, „eutanasia ai bimbi sotto $i 12$ anni”. Accessed August 28, 2015. http://www.avvenire.it/ Mondo/Pagine/Pediatrichoc-eutanasia-anche-ai-bimbi-sotto-i-12-anni-.aspx.
The Netherlands Ministry of Foreign Affairs. 2012. "Euthanasia." Accessed August 28, 2015. http://cdn.factcheck.org/UploadedFiles/2012/02/faqeuthanasia.pdf.

Timossi, Roberto. 2015. „«La prova» - pregiudizio dell'ateismo." Avvenire 183: 17.

Tommasi, Francesco V. 2015. Umanesimo profetico. La complicata relazione tra cattolicesimo e cultura. Cinisello Balsamo: Edizioni San Paolo.

Verrazzo, Simona. 2015. „In Colombia l'eutanasia con circolare ministeriale." Avvenire 96: 457.

Vinai, Emanuela. 2015. „Oggi l'ospedale di Reims decise su Vincent Lambert.” Avvenire 185: 470.

Wehrli, Hans, Bernhard Sutter, and Peter Kaufmann. 2015. Der organisierte Tod - Ster-behilfe und Selbstbestimmung am Lebensende. Pro und Contra. Mit Geleitwort von Hans Küng. Zürich: Orell Füssli Verlag.

Wet 2014 - Wet toetsing levensbeëindiging op verzoek en hulp bij zelfdoding. Accessed August 28, 2015. http://wetten. overheid.nl/BWBR0012410/geldigheids-datum_08-01-2014. 